\title{
Penyelenggaraan Sistem Pendidikan Tinggi Jarak Jauh di Perguruan Tinggi Swasta
}

\author{
Irwansyah ${ }^{1}$
}

\begin{abstract}
Abstrak
Dalam rangka upaya peningkatan Angka Partisipasi Kasar (APK) pemerintah melakukan terobosan baru dengan diperbolehkannya perguruan tinggi (selain Universitas Terbuka/UT) untuk menyelenggarakan Pendidikan Jarak Jauh (PJJ). Kebijakan tersebut tertuang dalam Peraturan Menteri Pendidikan dan Kebudayaan Nomor 24 Tahun 2012 tentang Penyelenggaraan Pendidikan Jarak Jauh pada Perguruan Tinggi. PJJ bertujuan untuk meningkatkan perluasan dan pemerataan akses terhadap pendidikan yang bermutu dan relevan sesuai kebutuhan. Semakin banyaknya masyarakat yang masuk ke perguruan tinggi (baik PTN maupun PTS), APK-PT bisa terdongkrak meningkat signifikan. Payung hukum bagi penyelenggara perguruan tinggi (baik PTN maupun PTS), antara lain adalah Permendikbud 109/2013 tentang Penyelenggaraan Pendidikan Jarak Jauh (PJJ) di Pendidikan Tinggi. Kenyataan lapangan yang terjadi dalam menyelenggarakan PJJ (baik PTN maupun PTS), masih sangat sedikit sekali dari segi jumlah (baru sembilan lembaga). Belum lagi dievaluasi dari segi kualitas penyelenggaraan sistem dan manajemennya, apakah telah optimal sesuai dengan ketentuan perundang-undangan dan peraturan dalam menyelenggarakan sebuah PJJ? Karena itu, sangatlah menarik gagasan ini untuk dianalisis antara peraturan perundangan yang berlaku, dengan realita lapangan, yang seyogyanya dilakukan penyesuaian-penyesuaian (fleksibilitas) dalam penyelenggaraan sistem dan manajemen PJJ-nya di perguruan tinggi (semacam keleluasan pengelolaan yang fleksibel). Oleh sebab itu menurut penulis, penyelenggara PJJ kenyataannya masih didominasi oleh PTN yang memiliki kapasitas besar, dan berskala nasional. Pertanyaannya, apakah dimungkinkan bagi PTS untuk menyelenggarakan PJJ-nya?
\end{abstract}

Kata Kunci: APK-PT, Peraturan dan Perundang-undangan yang berlaku, Jumlah penyelenggara PJJ yang masih sedikit, kemungkinan penyelenggaraan PJJ di PTS

\section{Pendahuluan}

Dalam rangka pelaksanaan UU Nomor 20 Tahun 2003 tentang Sistem Pendidikan Nasional, UU Nomor 12 Tahun 2012 tentang Pendidikan Tinggi, dan Peraturan Presiden Nomor 13 Tahun 2015 tentang Kemenristek Dikti, dalam Pasal 2 bahwa Kemenristek Dikti mempunyai tugas menyelenggarakan urusan pemerintahan di bidang riset, teknologi, dan pendidikan tinggi. Salah satu penyelenggara pendidikan tinggi tersebut adalah Universitas Terbuka (UT). UT sebagai penyelenggara pendidikan tinggi jarak jauh (PTJJ), memberikan kesempatan kepada masyarakat luas dengan ijazah minimal setingkat SLTA atau Paket C (setara SLTA), untuk mengikuti program pendidikan tingginya melalui program belajar jarak jauh (BJJ). UT menerapkan sistem belajar terbuka dan jarak jauh. Makna terbuka adalah UT tidak memberlakukan
Program Studi Manajemen

Fakultas Ekonomi

Universitas Pamulang,

Indonesia

EMail

Dosen01457@unpam.ac.id

Submitted : Juli 2018

Accepted : Juli 2018 
pembatasan usia, tahun ijazah, masa belajar, waktu registrasi, dan frekuensi mengikuti ujian. Lalu istilah jarak jauh berarti pembelajaran tidak melakukan secara tatapmuka, melainkan menggunakan media, baik media cetak (modul) maupun noncetak (audio, video, computer, internet, siaran radio, dan televisi (Katalog UT, Sistem Penyelenggaraan FE, FHISIP, FKIP, FMIPA, 2017/2018). Telah begitu banyak kontribusi UT untuk meningkatkan mutu dan kualifikasi SDM (baik S-1 maupun S-2) di seluruh Indonesia, dan masyarakat Indonesia di luar negeri. UT telah memberikan patokan dasar dalam menyelenggarakan sistem PTJJ (baik di PTN maupun di PTS).

Mungkinkah penyelenggaraannya di PTS? Bagaimana sistem dan manajemen/pengelolaannya?

Adapun ketentuan dan peraturan PJJ adalah sebagai berikut.

1) UU Sistem Pendidikan Nasional 20/2003.

2) UU Pendidikan Tinggi 12/2012.

3) Permendikbud 109/2013 tentang Penyelenggaraan Pendidikan Jarak Jauh di Pendidikan Tinggi.

4) Permendikbud 4/2014 Penyelenggaraan Pendidikan Tinggi.

5) Permendikbud 50/2014 tentang SPMI.

6) Permendikbud 87/2014 tentang Akreditasi.

7) Permenristekdikti 44/2015 tentang Stantar Nasional Pendidikan Tinggi.

8) Permenristekdikti 50/2015 tentang Pembukaan dan Pendirian PT.

9) Permenristekdikti 2/2016 tentang Registrasi Dosen

Pengertian Pendidikan Jarak Jauh (Prof.Dr. Pauline Pannen, 2016) adalah:

1) Proses pendidikan yang terorganisasi yang menjembatani keterpisahan antara siswa dengan pendidik dan dimediasi oleh pemanfaatan teknologi, dan pertemuan tatapmuka yang minimal.

2) Pendidikan jarak jauh ditawarkan lintas ruang dan waktu sehingga siswa memperoleh fleksibilitas belajar dalam waktu dan tempat yang berbeda, serta menggunakan beragam sumber belajar.

3) Biasanya berbentuk pendidikan massif Pendidikan Jarak Jauh (PJJ) berevolusi dari bentuk pendidikan koresponden sampai pendidikan melalui e-learning lintas ruang dan waktu.

Dalam UU No. 12/2012 tentang Pendidikan Tinggi, Bagian Ketujuh Pendidikan Jarak Jauh Pasal 31 butir 1) Pendidikan jarak jauh (PJJ) merupakan proses belajar mengajar yang dilakukan secara jarak jauh melalui penggunaan berbagai media komunikasi. 2) Pendidikan jarak jauh (PJJ) sebagaimana dimaksud pada ayat (1) bertujuan: a. memberikan layanan pendidikan tinggi kepada kelompok masyarakat yang tidak dapat mengikuti Pendidikan secara tatapmuka atau reguler; dan b. memperluas akses serta mempermudah layanan pendidikan tinggi dalam pendidikan dan pembelajaran . 3) Pendidikan jarak jauh (PJJ) diselenggarakan dalam berbagai bentuk, modus, dan cakupan yang didukung oleh sarana dan layanan belajar serta sistem penilaian yang menjamin mutu lulusan sesuai dengan

JAS-PT

JURNAL ANALISIS SISTEM PENDIDIKAN TINGG ISSN $2580-5339$ eISSN $2620-5718$

Volume 2

Nomor 1

JULI 2018

Hal 39- 50

FORUM DOSEN INDONESIA Standar Nasional Pendidikan Tinggi. 4) Ketentuan lebih lanjut mengenai penyelenggaraan pendidikan jarak jauh (PJJ) sebagaimana dimaksud pada ayat (1), ayat (2), dan ayat (3) diatur dalam Peraturan Menteri Ristek Dikti.

Media komunikasi. Teknologi informasi dan komunikasi (TIK) pendidikan jarak jauh (PJJ) adalah proses belajar mengajar yang dilakukan secara jarak jauh melalui penggunaan berbagai media komunikasi (Permendikbud No. 109/2013). 


\section{Pengertian e-learning adalah:}

1) Pembelajaran individu/mandiri atau kelompok menggunakan Teknologi Informasi, dan Komunikasi (TIK) dan jejaring.

2) Memberikan fleksibilitas untuk siswa belajar kapan saja, di mana saja, dan dengan siapa saja.

3) Dapat dikombinasikan dengan tatapmuka, pembelajaran blended, tetapi memiliki nilai inovatif karena memberikan nuansa baru dalam proses belajar mengajar yang berbeda dengan pembelajaran tatapmuka biasa.

E-learning is defined as flexible learning experiences delivered through the use of information and computer technologies to be accessible anytime, anywhere, by anyone (pengalaman belajar yang fleksibel yang memanfaatkan TIK dan dapat diakses kapan saja, di mana saja, oleh siapa saja).

\section{Prinsip Pendidikan Terbuka}

Prinsip 1: Pendidikan Terbuka.

Bahwa setiap individu memiliki kesempatan belajar tanpa hambatan apapun (Bates, 1995). Implementasi praktisnya: siapapun bisa mendaftar menjadi mahasiswa kapanpun, bebas mengambil matakuliah, bebas menyelesaikan pendidikannya tanpa batas waktu.

Prinsip 2: Pendidikan Jarak Jauh Prinsip PJJ.

a. Adanya keterpisahan antara pendidik dan peserta didik lintas ruang dan waktu sehingga lebih menekankan pada belajar secara mandiri.

b. Interaksi pembelajaran berbasis TIK menggunakan berbagai sumber belajar TIK dan media lain.

c. Diorganisasikan secara sistematis dalam satu organisasi sesuai aturan yang berlaku.

d. Dimungkinkan adanya tatapmuka secara terbatas.

Implikasi praktis: (1) Memiliki jangkauan yang luas lintas ruang dan waktu. (2) Menyediakan keluwesan belajar bagi peserta didik lintas ruang dan waktu. (3) Massal dan terorganisasi. (4) Memanfaatkan teknologi informasi dan komunikasi (TIK).

Prinsip 3: Pemanfaatan TIK dalam Pembelajaran Tatapmuka - Terpadu - Online

\begin{tabular}{|c|c|c|}
\hline Proporsi Online & Deskripsi & Tipe \\
\hline $0 \%$ & $\begin{array}{ll}\text { Tatapmuka } & \text { sepenuhnya, } \\
\text { pembelajaran dengan bahan ajar } \\
\text { cetak atau lisan. }\end{array}$ & Tatapmuka tradisional. \\
\hline $1 \%$ s.d. $29 \%$ & $\begin{array}{l}\text { Menggunakan teknologi internet } \\
\text { untuk memfasilitasi pola tatapmuka, } \\
\text { mungkin menggunakan LMS atau } \\
\text { situs web untuk mem-poskan bahan } \\
\text { ajar dan tugas. }\end{array}$ & $\begin{array}{l}\text { Web-enhanced } \\
\text { (pembelajaran } \\
\text { diperkaya dengan } \\
\text { akses Internet). }\end{array}$ \\
\hline $30 \%$ s.d. $79 \%$ & $\begin{array}{l}\text { Mengombinasikan cara online dan } \\
\text { tatapmuka. Ada proporsi pengantaran } \\
\text { bahan ajar yang online, biasanya } \\
\text { dilengkapi dengan diskusi online, dan } \\
\text { ada pengurangan frekuensi } \\
\text { tatapmuka. }\end{array}$ & $\begin{array}{l}\text { Blended/Hybrid } \\
\text { learning). }\end{array}$ \\
\hline$>80 \%$ & $\begin{array}{l}\text { Sebagian besar atau seluruh bahan } \\
\text { ajar diantarkan secara online, bisa } \\
\text { tanpa porsi tatapmuka sama sekali. }\end{array}$ & $\begin{array}{l}\text { Fully Online } \\
\text { learning). }\end{array}$ \\
\hline
\end{tabular}

JAS-PT

JURNAL ANALISIS SISTEM PENDIDIKAN TINGGI ISSN $2580-5339$ eISSN $2620-5718$ Volume 2 Nomor 1

JULI 2018

Hal $39-50$ 


\section{Penyelenggaraan PJJ di Indonesia.}

a. Pelatihan guru tertulis.

b. Universitas Terbuka (UT).

c. Hybrid Learning for Indonesian Teachers (HYLITE: PJJ S1 PGSD - 23 LPTK) pada Kemdikbud.

d. PJJ untuk Politeknik oleh PENS (Surabaya State Politechnics for Electronics).

e. GDLN - Universitas Indonesia (UI).

f. Dual Mode Education Model pada Universitas Pendidikan Indonesia (UPI) Bandung.

g. Model Universitas Negeri Semarang (Unnes).

h. ITB - Seamolec.

i. Distance education for Contonuing Vocasional Education - Seamolec.

Paparan di atas memberikan pemahaman bahwa antara peraturan perundangan yang berlaku dengan realisasi penyelenggaraan PJJ di perguruan tinggi, memiliki dinamika masing-masing kesulitan dalam menerapkan PJJ di perguruan tingginya masingmasing. Karena itu, tidaklah berlebihan bahwa tulisan gagasan dan analisis ini penulis kemukakan mengenai "Penyelenggaraan Sistem Pendidikan Tinggi Jarak Jauh/PTJJ di Perguruan Tinggi Swasta/PTS". (suatu gagasan dan analisis sistem dan manajemen pendidikan tinggi melalui PJJ pada suatu program studi).

\section{Metode}

Guna menganalisis "Penyelenggaraan Sistem Pendidikan Tinggi Jarak Jauh/PTJJ di Perguruan Tinggi Swasta/PTS". (suatu gagasan dan analisis sistem dan manajemen pendidikan tinggi melalui PJJ pada suatu program studi), perlu diperhatikan apa-apa sajakah yang menjadi komponen penyelenggaraan sistem PTJJ? Lalu apa sajakah keterkaitan antarsuatu sistem dengan sistemnya dalam penyelenggaraan PJJ? Kemudian kemungkinan pilihan program studi, apakah yang akan dilakukan dan diselenggarakan melalui PJJ? Lalu pilihan modus PJJ (tunggal, ganda, konsorisum) yang manakah yang akan diselenggarakan? Kemudian dari hal-hal di atas, perlu dilakukan pemilihan metode apakah yang dimungkinkan relevan untuk masing-masing pertanyaan atas sistem dan manajemen PJJ-nya?

Definisi Modus tunggal PJJ, diselenggarakan pada semua proses pembelajaran pada matakuliah atau program studi. Sedangkan definisi Modus ganda PJJ merupakan penyelenggaraan PJJ pada matakuliah atau program studi secara tatapmuka dan jarak jauh. Lalu Modus konsorsium PJJ diselenggarakan oleh beberapa program studi dalam bentuk jejaring kerja sama dengan lingkup perguruan tinggi yang bersangkutan atau antarperguruan tinggi dalam wilayah nasional dan/atau internasional.

Dalam konteks gagasan dan analisis yang penulis kemukakan dalam karya ini, adalah hanya pada Modus ganda PJJ merupakan penyelenggaraan PJJ pada matakuliah atau program studi secara tatapmuka dan jarak jauh.

Karena itu metode analisis yang digunakan penulis adalah berpijak pada analisis "deskriptif penyelenggaraan" yaitu analisis:

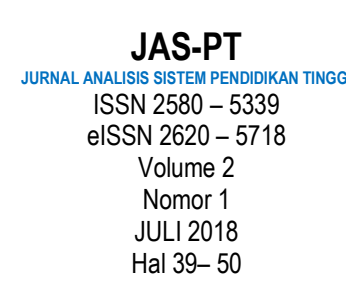

FORUM DOSEN INDONESIA
1) komponen penyelenggaraan;

2) sistem penyelenggaraan;

3) manajemen SDM, dan NonSDM dalam penyelenggaraan;

4) pilihan program studi yang akan diselenggarakan dalam PJJ di PTS; dan

5) Modus ganda PJJ merupakan penyelenggaraan PJJ pada matakuliah atau program studi secara tatapmuka dan jarak jauh. 


\section{Keadaan saat ini}

Sepengetahuan penulis, dalam rangka menyiapkan konsep dan rencana menerapkan "Penyelenggaraan Sistem Pendidikan Tinggi Jarak Jauh/PTJJ di Perguruan Tinggi Swasta/PTS". (suatu gagasan dan analisis sistem dan manajemen pendidikan tinggi melalui PJJ pada suatu program studi), dugaan penulis adalah masih belum terpublikasikannya atas hasil suatu seminar ataupun workshop-nya. Karena itu, sangatlah menarik untuk dijadikan suatu gagasan ataupun model analisis PJJ dalam jurnal sistem dan manajemen pendidikan tinggi, dan lebih khusus lagi penyelenggaraannya di suatu PTS.

\section{Keadaan yang Diharapkan}

Diharapkan dengan adanya analisis ini, akan diperoleh suatu kecenderungan alternatif model PJJ suatu program studi di PTS untuk diselenggarakan PJJ-nya. Tentunya memerlukan pendalaman dalam suatu diskusi akademis yang terbuka, dan pada akhirnya menemukan modelnya. Semoga saja terwujud.

\section{Hasil dan Pembahasan}

\section{Analisis komponen penyelenggaraan.}

1. Komponen "manajemen/pengelola kebijakan" PJJ.

Komponen ini memberikan arahan kepada manajemen internal perguruan tinggi (dhi. PTS) yang menerapkan PJJ agar menyiapkan konsep (berdasarkan fakta dan pengalaman yang diperoleh, serta definisi yang diyakini) yang dibuat oleh pengelola kebijakan PJJ perguruan tinggi (dhi. PTS yang bersangkutan). Sebagai contoh, kebijakan sistem pengelolaan standar registrasi pebelajar (yang merupakan komitmen semua pihak untuk melaksanakannya), yang dibuat oleh tim yang mengembangkan standar-standar dan pedoman serta panduan-panduan pelaksanaannya (baik bagi "manajemen/pengelola kebijakan" PJJ, maupun bagi "manajemen/pengelola pelaksana" kebijakan PJJ di suatu wilayah). Lalu bagaimana caranya menerapkannya di suatu wilayah, agar sistem dan prosedur yang dibakukan dioperasikan/dijalankan oleh "manajemen/pengelola pelaksana" kebijakan PJJ di suatu wilayah. Tentunya harus melalui suatu proses a) pengembangan berdasarkan pengalaman, b) integrasi konsep, c) penyempurnaan konsep, d) uji coba konsep, e) revisi konsep, f) siap implementasi konsep, dan g) evaluasi dan umpan balik (feed back), dari kondisi di lapangan guna lebih menyempurnakan sistem dan prosedur yang baku atas konsep sistem, prosedur, pedoman, dan panduan instruksi kerja.

Selain subkomponen sistem, prosedur, pedoman, dan panduan instruksi kerja, diperlukan subkomponen teknologi, informasi, dan komunikasi (TIK) yang dikembangkan oleh tenaga terampil TIK yang membuat dukungan pemercepatan proses dalam pencapaian tujuan, dengan meminimalisir tenaga manusia. TIK memegang peran pokok dan penting dalam menyiapkan "manajemen/pengelola kebijakan" PJJ untuk diselenggarakan oleh semua pemangku kepentingan (stake holders).

Selain 2 (dua) hal subkomponen yakni 1) sistem, prosedur, pedoman, dan panduan instruksi kerja, dan 2) subkomponen teknologi, informasi, dan komunikasi (TIK), yang juga tidak kalah pentingnya adalah subkomponen sarana dan prasarana guna mendukung "manajemen/pengelola kebijakan" PJJ. Sebagai contoh adalah pengadaan gedung atau ruang kerja (termasuk meja dan kursi), instalasi kelistrikan, komputerisasi,

\footnotetext{
JAS-PT

JURNAL ANALISIS SISTEM PENDIDIKAN TINGGI ISSN $2580-5339$ elSSN $2620-5718$ Volume 2 Nomor 1 JULI 2018 Hal $39-50$

FORUM DOSEN INDONESIA
} 
jaringan, dan sebagainya, demi kelancaran terselenggaranya "manajemen/pengelola kebijakan" PJJ bagi semua pihak pemangku kepentingan (stake holders). Juga dukungan keuangan/finansial yang sangat vital dalam keberhasilan pelaksanaan "manajemen/pengelola kebijakan" PJJ, yang perlu diatur sistem dan prosedurnya dalam a) perencanaan program, b) pelaksanaan kemajuan dan realisasi program, serta yang belum terealisasi programnya, c) pertanggungjawaban keuangan atas program yang diselenggarakan.

Dari 3 (tiga) subkomponen di atas, yang terpenting adalah komponen SDM pembuat kebijakan dan pelaksana kebijakan tersebut, yang memiliki kompetensi mumpuni, terjamin, jujur, terbuka, disiplin, bertanggungjawab, dan ingin menyempurnakan sistem dan manajemennya. Disinilah perlunya kaderisasi SDM yang mesti disiapkan untuk jangka panjang dalam menerapkan PJJ yang lebih sempurna lagi ke depannya dengan pemanfaatan optimalisasi TIK dan SDM yang terintegrasi dan terpadu dalam melaksanakannya. Juga pemilihan SDM yang memiliki kompetensi untuk menduduki suatu jabatan, dengan pengamatan yang direncanakan secara berkelanjutan, proses dan prosedur pemilihan yang telah sesuai kaidah, dan sustainable guna memilih subjek pemimpin yang memiliki kompetensi dan tangguh dalam menghadapi tantangan yang ada di depan mata (problem solving).

2. Komponen "manajemen/pengelola pelaksana" kebijakan PJJ di suatu wilayah. Komponen ini, merupakan tataran manajemen/pengelola pelaksana di suatu wilayah, yang siap untuk melaksanakan tugas, kebijakan dari pusat. Subkomponennya paling tidak, terdiri atas wakil kelompok a) fungsional dosen perwakilan masing-masing fakultas, dan program studi, b) peneliti, c) pustakawan, d) TIK (ICT), e) Teknologi Pembelajaran (TP), f) desain komunikasi visual, dan g) marketing. Kemudian ditambah lagi tenaga teknisi a) kelistrikan, b) kehumasan, c) administrator, d) ilustrator dan karikatur, e) dan lainnya sesuai kebutuhan wilayah.

3. Komponen "pengembangan sistem dan manajemen PJJ".

Komponen ini, tugas pokoknya adalah mengembangkan dan menganalisis, serta dapat mengidentifikasi kemungkinan risiko yang minimal diterima bagi pengelola (jika mungkin zero defect), dan bisa diterima oleh pengelola, dengan melakukan formulasi model sistem PJJ suatu program studi yang diinginkan, dan sangat mungkin bisa diterapkan. Dalam konteks analisis PJJ ini, penulis memilih program studi yang sifatnya umum, tatapmuka, dan telah diselenggarakan di suatu PTS, yaitu program studi S-1 Manajemen. Tentunya memiliki kemiripan kurikulum (antarPTS dengan PTS yang lainnya) dengan standar kompetensi lulusan S-1 Manajemen bagi suatu PTS yang minimal berakreditasi B. Hendaknya dilakukan pemilihan matakuliah-matakuliah yang serumpun, misalnya rumpun SDM (untuk matakuliah-matakuliah manajemen SDM, perencanaan manajemen SDM, pengembangan SDM, dan audit SDM), untuk kemudian disepakati mana yang dilakukan tatapmuka, dan mana yang dilakukan jarak jauh? Hal ini mempertimbangkan pengembangan bahan ajar cetak, dan bahan ajar multimedianya, yang memerlukan ahli profesionalnya masing-masing (baik substansi isi maupun kemenarikan tampilannya, dan enak, serta nyaman untuk dilihat dengan mata normal).

JAS-PT

ISSN $2580-5339$ eISSN $2620-5718$

Volume 2

Nomor 1

JULI 2018

Hal $39-50$
4. Komponen "pengembangan bahan ajar dan media".

Komponen ini merupakan komponen sangat vital dan sangat penting. Karena pengembangan bahan ajar (cetak maupun noncetak), dan media pembelajarannya, memerlukan keahlian dan keterampilan tersendiri. Karena itu diperlukan penulis ahli bidang studi suatu bahan ajar yang profesional dalam mengembangkan substansinya, sesuai dengan format instruksional standar, komunikatif (pengemasan antara deskripsi 
substansi dan desain komunikasi visual yang integratif) dengan pembaca bahan ajarnya.

Bahan ajar cetak, merupakan dosennya bagi PJJ. Sedangkan bahan ajar noncetak merupakan pelengkap bahan ajar cetak yang dapat membantu peningkatan pemahaman pebelajar. Kemudian pendamping belajar mahasiswa, adalah tutor (baik tutor tatapmuka, maupun tutor online), dengan tetap berpijak pada sistematika instruksional bahan ajar suatu matakuliah yang standar. Karena itu memerlukan pemikiran integratif sistem dalam pengembangan bahan ajar, dan pemilihan multimedianya. Belum lagi penggandaannya memerlukan waktu, pemeriksaan kualitas substansi yang standar. Termasuk delivery dan pengemasan yang menarik paket bahan ajarnya, yang akan dikirim ke mahasiswa selaku pebelajar.

5. Komponen "pengembangan teknologi informasi, dan komunikasi" (TIK).

Komponen ini, menganalisis pemanfaatan TIK dalam kemasan PJJ. Pemilihan bahan ajar cetak prodi yang dipilih (misalnya, prodi S-1 manajemen), dan telah ditentukannya matakuliah-matakuliah mana yang melalui kuliah tatapmuka dan melalui PJJ, hendaknya tidak terpisahkan (terintegratif) dengan multi medianya, yang nyata-nyata memanfaatkan TIK, dan sumber-sumber belajar lainnya (sebagai pengayaan).

6. Komponen "registrasi, dan pengujian".

Komponen ini, memerlukan sistem dan manajemen tersendiri yang juga hendaknya memadukan antara registrasi manual, dan registrasi online. Karena itu diperlukan pedoman standar operasional, dan petunjuk (instruksi) kerja bagi petugas sebagai kelengkapan dari pedoman standar operasional tersebut. Hal ini dimaksudkan untuk memudahkan bagaimana data calon mahasiswa (dan pencatatannya sebagai mahasiswa/pebelajar), dapat direkam oleh sistem informatika, guna pemanfaatan komunikasi antara manajemen/pengelola PJJ dengan mahasiswa ketika a) melakukan layanan delivery bahan ajar (baik secara fisik bahan ajar, maupun media sosial lainnya), b) layanan bantuan belajar (baik melalui tatapmuka maupun online, ataupun dengan pendampingan bantuan belajar lainnya), c) layanan ujian dan hasil ujian, d) layanan wisuda dan pengiriman ijazah, e) layanan informasi perguruan tinggi, misalnya tawaran meningkatkan strata pendidikannya yang lebih tinggi, ataupun program sertifikasi per matakuliah tertentu, yang pada suatu waktu bisa diakui dalam suatu kurikulum program studi tertentu, dan f) keperluan lainnya.

7. Komponen "distribusi bahan ajar, dan bantuan belajar,".

Subkomponen distribusi bahan ajar ini, memerlukan sistem dan manajemen internal tersendiri lagi, yakni mulai prediksi jumlah mahasiswa pebelajar sebagai peserta program (misalnya S-1 Manajemen), pada semester berikutnya (Sem. +1), Sem. +2, Sem. +3 , dan seterusnya. Hal prediksi jumlah mahasiswa ini, dimaksudkan untuk proyeksi jumlah penggandaan bahan ajar/modul, dan multimedianya. Lalu sistem pemaketan bahan ajar dalam suatu semester berjalan, dan penyiapan pemaketan semester berikutnya, serta pemaketan setiap semesternya. Pengalaman penulis, ternyata tidak semudah apa yang dibayangkan oleh sebagai pengelola PJJ. Kemudian pengaturan sistem dan manajemen (dengan pemanfaatn TIK) yang dimulai dari pemesanan pemaketan bahan ajar (beserta multi medianya) oleh mahasiswa (melalui online), dan sistem layanan pembelian secara langsung ke perguruan tinggi. Inipun tidak semudah yang dibayangkan dalam pengaturan manajemennya. Hal ini memerlukan pengendapan konsep yang dipadukan dengan pengalaman lapangan, yang diformulasikan (dibuat modelnya) secara tersendiri.

Selanjutnya adalah subkomponen layanan bantuan belajar, yakni bagaimana perguruan tinggi memberikan layanan bantuan belajar (baik melalui tatapmuka, maupun secara jarak jauh (online), beserta cara mendapatkan bantuan belajar, dan

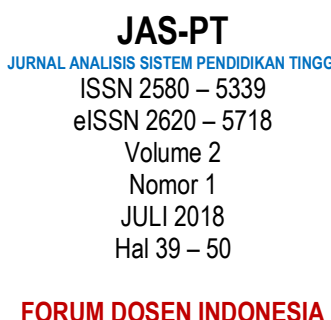

FORUM DOSEN INDONESIA 
instruksi kerja bagi mahasiswa yang memilih bantuan belajar secara jarak jauh (online), melalui pedoman, dan instruksi kerja (baik bagi pengelola manajemen PJJ perguruan tinggi, dan mahasiswa selaku pebelajar peserta program). Layanan bantuan belajar melalui tatapmuka, diperlukan penjadwalan, penentuan frekuensi pertemuan tatapmuka, sistem rancangan bantuan belajarnya setiap pertemuannya beserta substansi/isi, tutor sebagai fasilitator mahasiswa dalam memberikan bantuan belajar agar tujuan pembelajaran dan kompetensi dapat tercapai. Bantuan belajar oleh tutor selaku pendamping belajar mahasiswa, akan berkontribusi pada nilai ujian akhir semester (UAS). Proporsi bobot nilai antara skor penilaian mahasiswa yang mengikuti bantuan belajar secara tatapmuka oleh tutor, maupun skor penilaian mahasiswa yang mengikuti bantuan belajar secara online, dari tutor, memerlukan standar bobot nilai yang disepakati oleh program studi perguruan tinggi yang menyelenggarakan PJJ-nya.

8. Komponen "mahasiswa/pebelajar" PJJ.

Komponen pokok dalam penyelenggaraan PJJ adalah mahasiswa peserta program pendidikan PJJ selaku pebelajar. Karena itu manajemen perguruan tinggi, hendaknya memberikan layanan terbaiknya terhadap mahasiswa peserta program pendidikan PJJ selaku pebelajar. Hal ini dimaksudkan agar mahasiswa peserta program pendidikan PJJ, tidak meninggalkan kuliahnya di program pendidikan yang diikutinya (drop out) tanpa keterangan yang diperoleh perguruan tinggi. Karena itu pula sistem dan manajemen perguruan tinggi, hendaknya melakukan monitoring dan evaluasi secara berkelanjutan, guna penyempurnaan sistem dan pengelolaannya dalam memberikan layanan optimalnya (layanan prima) kepada mahasiswa selaku pebelajar.

\section{Analisis Sistem Penyelenggaraan}

Berdasarkan 8 (delapan) komponen penyelenggaraan yang dianalisis di atas di dalam sistem penyelenggaraan PJJ pada suatu program studi tertentu (misalnya, S-1 Manajemen) di PTS, maka diperlukan pedoman "payung" yang disepakati pimpinan PTS secara bersama-sama. Lalu perlu pula pedoman standar (baik sistem tahapan dan prosedur yang semestinya dilaksanakan oleh semua pihak secara konsisten dan memiliki komitmen tinggi). Yang tidak kalah pentingnya dalam mengembangkan sistem dan manajemen PJJ di PTS, adalah leadership dan komitmen para stakeholders dalam merencanakan, dan mengelolanya, serta tercapainya tujuan penyelenggaran PJJ di PTS, dengan kreativitas dan inovasinya.

\section{Analisis manajemen SDM, dan NonSDM dalam penyelenggaraan}

Berdasarkan analisis 8 (delapan) komponen penyelenggaraan yang dianalisis di atas, maka sangatlah diperlukan SDM yang berkompeten dalam mengembangkan sistem dan manajemen PJJ tersebut, sampai terselenggarakannya program PJJ di PTS, baik yang diawali dari perencanaan sistem dan manajemen (SDM dan NonSDM), pelaksana sistem dan pengelolaannya, yang memerlukan simulasi dan pelatihan tersendiri. Apabila telah terencana dan terprogram dengan baik, bukan hal yang tidak mungkin, dan pasti dapat dilaksanakan, walaupun mungkin disana-sini masih terdapat kekurangan dalam penyelenggaraannya. Disinilah peran monitoring dan evaluasi, guna menyempurnakan sistem dan manajamen perguruan tinggi, dalam mengembangkan

JAS-PT

JURNAL ANALSIS SISTEM PENDIDIKAN TINGG ISSN $2580-5339$ eISSN $2620-5718$

Volume 2

Nomor 1

JULI 2018

Hal $39-50$ sistem dan manajemennya. Tak ada gading yang tak retak, dan jangan berputus harapan, untuk menyiapkan SDM dan NonSDM-nya yaitu sarana dan prasarana penunjang dalam penyelenggaraan PJJ di PTS. Misalnya, a) ruang kerja beserta perlengkapannya, b) lalu jaringan komputer beserta perangkat lainnya, c) ATK, d) tenaga terampil bidang TIK, e) rekrutmen SDM yang sesuai kompetensinya, f) arahan 
pimpinan perguruan tinggi kepada tim pengembang sistem untuk mencapai visi dan misinya yang secara terus menerus berkelanjutan, g) dan banyak hal lainnya.

\section{Analisis pilihan program studi yang akan diselenggarakan dalam PJJ di PTS.}

Definisi Modus tunggal PJJ, diselenggarakan pada semua proses pembelajaran pada matakuliah atau program studi. Sedangkan definisi Modus ganda PJJ merupakan penyelenggaraan PJJ pada matakuliah atau program studi secara tatapmuka dan jarak jauh. Lalu definisi Modus konsorsium PJJ diselenggarakan oleh beberapa program studi dalam bentuk jejaring kerja sama dengan lingkup perguruan tinggi yang bersangkutan atau antarperguruan tinggi dalam wilayah nasional dan/atau internasional.

Dalam konteks analisis yang penulis kemukakan, adalah hanya pada Modus ganda PJJ merupakan penyelenggaraan PJJ pada matakuliah atau program studi secara tatapmuka dan jarak jauh. Artinya kita mesti mengelompokkannya terlebih dahulu matakuliah-matakuliah yang serumpun dalam kurikulum S-1 Manajemen di PTS, misalnya rumpun 1) manajemen, 2) rumpun SDM, 3) rumpun eksakta dan noneksakta, 4) dan seterusnya.

Pemanfaatan TIK dalam Pembelajaran Tatapmuka-Terpadu-Online, dalam hal proporsi online seperti dinyatakan oleh Prof. Dr. Pauline Pannen, 2016, perlu mendapatkan fokus pertimbangan untuk dilaksanakan secara konsisten yaitu:

\begin{tabular}{|c|l|l|}
\hline Proporsi Online & \multicolumn{1}{|c|}{ Deskripsi } & \multicolumn{1}{|c|}{ Tipe } \\
\hline $30 \%$ s.d. $79 \%$ & $\begin{array}{l}\text { Mengombinasikan cara online dan } \\
\text { tatapmuka. Ada proporsi pengantaran }\end{array}$ & $\begin{array}{l}\text { Blended/Hybrid (e- } \\
\text { learning). }\end{array}$ \\
& $\begin{array}{l}\text { bahan ajar yang online, biasanya } \\
\text { dilengkapi dengan diskusi online, dan } \\
\text { ada pengurangan frekuensi tatapmuka. }\end{array}$ & \\
\hline
\end{tabular}

Oleh sebab itu, berdasarkan rumpun matakuliah pada program studi S-1 Manajemen pada PTS, hendaknya dipilih matakuliah-matakuliah, mana yang penyelenggaraan kuliahnya melalui tatapmuka, dan mana yang melalui online? Format isiannya perlu diciptakan sedemikian rupa, sehingga memudahkan tim untuk mengidentifkasi dan mengolahnya.

\section{Analisis Modus ganda PJJ merupakan penyelenggaraan PJJ pada matakuliah atau program studi secara tatapmuka dan jarak jauh.}

Dalam rangka upaya peningkatan Angka Partisipasi Kasar (APK) pemerintah melakukan terobosan baru dengan diperbolehkannya perguruan tinggi (selain Universitas Terbuka/UT) untuk menyelenggarakan Pendidikan Jarak Jauh (PJJ). Kebijakan tersebut tertuang dalam Peraturan Menteri Pendidikan dan Kebudayaan Nomor 24 Tahun 2012 tentang Penyelenggaraan Pendidikan Jarak Jauh pada Perguruan Tinggi.

Fungsinya adalah sebagai bentuk pendidikan bagi peserta didik yang tidak dapat mengikuti pendidikan tatapmuka tanpa mengurangi kualitas pendidikan. PJJ bertujuan untuk meningkatkan perluasan dan pemerataan akses terhadap pendidikan yang bermutu dan relevan sesuai kebutuhan.

Dengan semakin banyaknya masyarakat yang masuk ke perguruan tinggi (baik PTN maupun PTS), APK-PT dimungkinkan terdongkrak meningkat signifikan.

Perundang-undangan mengenai pendidikan tinggi jarak jauh (PTJJ) telah memberikan payung hukum bagi penyelenggara perguruan tinggi (baik PTN maupun PTS), antara

\footnotetext{
JAS-PT

JURNAL ANALISIS SISTEM PENDIDIKAN TINGGI ISSN $2580-5339$ elSSN $2620-5718$

Volume 2

Nomor 1

JULI 2018

Hal $39-50$
}

FORUM DOSEN INDONESIA 
lain adalah Permendikbud 109/2013 tentang Penyelenggaraan Pendidikan Jarak Jauh (PJJ) di Pendidikan Tinggi. Contoh terbaik (best practice) dalam hal PJJ ini adalah penyelenggaraan di Universitas Terbuka (UT) sejak 1984 s.d. 2018 ini (34 tahun). Kenyataan lapangan yang terjadi dalam menyelenggarakan PJJ (baik PTN maupun PTS), masih sangat sedikit sekali dari segi jumlah (baru sembilan lembaga). Belum lagi dievaluasi dari segi kualitas penyelenggaraan sistem dan manajemennya, apakah telah optimal sesuai dengan ketentuan perundang-undangan dan peraturan dalam menyelenggarakan sebuah PJJ?

Apabila dikaitkan dengan seberapa besarkah (dari segi jumlah), pemerintah (melalui Menristek Dikti), sudah berapakah jumlah masyarakat Indonesia telah berpendidikan tinggi? Tentu upaya sampai saat ini, masih terus berlanjut dalam mengimplementasikan kebijakannya. Karena saat ini, masyarakat bangsa ini telah sadar menyekolahkan putra-putri mereka untuk dapat mengenyam sekolah pada tingkat ataupun jenjang pendidikan tinggi atau perguruan tinggi. Bangsa ini telah banyak sekali memiliki perguruan tinggi (PTN maupun PTS) yang memberikan kesempatan kepada masyarakat untuk berperanserta dalam mengikuti sebagai peserta program bidang studi tertentu (sebagai mahasiswa) tatapmuka (konvensional), baik pada jenjang Diploma (I, II, III, IV), dan Sarjana Strata (I, II, III), serta Spesialis (I dan II). Tentu Kemenristek Dikti tengah berupaya meningkatkan kualitas penyelenggaraannya (baik secara tatapmuka maupun jarak jauh) melalui standar Akreditasi BAN-PT (baik akreditasi perguruan tinggi maupun akreditasi program studi).

Karena itu, sangatlah menarik gagasan ini untuk dianalisis antara peraturan perundangan yang berlaku, dengan realita lapangan, yang seyogyanya dilakukan penyesuaian-penyesuaian (fleksibilitas) dalam penyelenggaraan sistem dan manajemen PJJ-nya di perguruan tinggi (semacam keleluasan pengelolaan yang fleksibel). Karena menurut penulis, investasi dalam penyelenggaraan sistem dan manajemen PJJ, sangatlah mahal. Karena itu, penyelenggara PJJ kenyataannya masih didominasi oleh PTN yang memiliki kapasitas besar, dan berskala nasional. Pertanyaannya, apakah dimungkinkan bagi PTS untuk menyelenggarakan PJJnya?

Menurut Permendikbud nomor 24 tahun 2012, PJJ dapat diselenggarakan pada lingkup program studi atau matakuliah. PJJ dalam program studi diselenggarakan dalam proses pembelajaran pada $50 \%$ atau lebih, matakuliah dalam satu program studi. Sedangkan PJJ dalam matakuliah diselenggarakan di semua proses pembelajaran dalam satu matakuliah.

Izin penyelenggaraan PJJ untuk program studi dapat diberikan apabila:

1) Mempunyai izin penyelenggaraan program studi secara tatap muka dalam bidang studi yang sama.

2) Telah diakreditasi oleh lembaga akreditasi yang diakui pemerintah dengan nilai paling rendah $\mathrm{B}$, dan

3) Jumlah matakuliah yang diselenggarakan secara PJJ berjumlah lebih atau sama dengan $50 \%$ dari jumlah semua matakuliah dalam satu program studi yang dilaksanakan dengan tatap muka secara penuh

JAS-PT

ISSN $2580-5339$

eISSN $2620-5718$

Volume 2

Nomor 1

JULI 2018

Hal 39- 50

Dalam konteks analisis komponen ini, hendaknya kita mesti mengelompokkannya terlebih dahulu matakuliah-matakuliah yang serumpun dalam kurikulum S-1 Manajemen di PTS, misalnya rumpun 1) manajemen, 2) rumpun SDM, 3) rumpun eksakta dan noneksakta, 4) dan seterusnya. 
Proporsi online diantara $30 \%$ s.d. $79 \%$, adalah dengan mengombinasikan cara online dan tatapmuka. Ada proporsi pengantaran bahan ajar yang online, biasanya dilengkapi dengan diskusi online, dan ada pengurangan frekuensi tatapmuka. Pengantaran bahan ajar melalui online hendaknya diperlukan strategi pengompresan/peringkasan substansi materi Kegiatan Belajar (yang merupakan intisari dari perkuliahan tatapmuka, yang disajikan dalam bahan ajar/modul), hendaknya dijelaskan sedemikian rupa oleh dosen professional (selaku ahli penulis bahan ajar), tentunya dengan bantuan desain komunikasi visual yang semenarik mungkin, agar pembaca bahan ajar nyaman membacanya. Hasil pengompresan/peringkasan substansi materi Kegiatan Belajar, merupakan stimulan/ rangsangan bagi mahasiswa (pebelajar) peserta matakuliah yang diambil, untuk berdiskusi dengan teman mahasiswa (pebelajar) peserta matakuliah lainnya. Tentunya bantuan belajar online ini hendaknya didampingi oleh tutor selaku oarng yang selalu setiap saat mengarahkan dan melakukan encouragement kepada mahasiswa (pebelajar) peserta matakuliah, untuk selalu kembali ke rel garis-garis yang telah dituangkan dalam bahan ajar. Karena bahan ajar merupakan dosennya, dalam sistem PJJ.

Biasanya setiap materi bahan ajar terdiri atas 2 atau 3 Kegiatan Belajar, dan tergantung berapa SKS matakuliah tersebut memiliki bobotnya? Pengompresan/peringkasan substansi materi Kegiatan Belajar, dalam penyelenggaraan tutorial online dapat dilakukan 3 atau 4 tahap pengompresan/peringkasan. Hal ini dimaksudkan untuk pengelompokkan ukuran pemahaman substansi isi bahan ajar yang dikuasai oleh mahasiswa (pebelajar).

Dalam penyelenggaraan tutorial online, biasanya dilakukan selama 8 (delapan) kali inisiasi dalam online, atau selama 8 (delapan) minggu. Misalnya Setiap 3 inisiasi online, dilakukan tugas oleh tutor kepada mahasiswa (pebelajar), yang bisa disebut tugas 1 (T1). Lalu untuk inisiasi online ke-5, dilakukan tugas oleh tutor online kepada mahasiswa (pebelajar), yang bisa disebut tugas 2 (T-2). Kemudian untuk inisiasi online ke-7, dilakukan tugas oleh tutor online kepada mahasiswa (pebelajar), yang bisa disebut tugas 3 (T-3). Atau apabila dengan tetap frekeunsi selama 8 (delapan) tutorial online, bisa dilakukan dengan setiap selesai inisiasi online 1 dan 2, dilakukan tugas 1 (T-1). Lalu setiap inisiasi online 3 dan 4, dilakukan tugas 2 (T-2). Kemudian setiap inisiasi online 5 dan 6 , dilakukan tugas 3 (T-3). Lalu setiap inisiasi online 7 dan 8 (yang terakhir), dilakukan tugas 4 (T-4). Terhadap setiap pemberian skor/nilai dari tutor online atas T-1, T-2, T-3, atau sampai dengan T-4 pada gilirannya akan memberikan bobot ataupun kontribusi terhadap nilai akhir suatu matakuliah.

Misalnya saja skor/nilai hasil tutorial online secara keseluruhan (T-1, T-2, dan T-3) adalah $40 \%$. Dan hasil skor/nilai Ujian Akhir Semester (UAS) adalah minimal lulus $40 \%$. Maksudnya adalah apabila dalam UAS terdapat 60 (enam puluh) butir soal, maka $40 \%$ dari jumlah butir soal 60 butir soal yaitu $40 \% \times 60=24$ (dua puluh empat butir soal) wajib minimal berhasil dijawab dengan benar oleh mahasiswa (pebelajar). Sehingga akumulasi skor/nilai UAS ini akan berkontribusi terhadap nilai akhir mahasiswa (pebelajar), dan ditambah dengan skor/nilai hasil tutorial online secara keseluruhan (T-1, T-2, dan T-3) adalah $40 \%$. Maka apabila dijumlah diperoleh nilai akhir mahasiswa (pebelajar) $40 \%+40 \%=80 \%$ (memperoleh skor/nilai A). Apabila mahasiswa (pebelajar) hanya dapat menjawab 22 butir (dibawah $\leq 40 \%$ ), maka mahasiswa (pebelajar) sudah dipastikan tidak lulus pada perhitungan nilai akhir pada suatu matakuliah. Karena itulah, mahasiswa (pebelajar) wajib menjawab soal dengan benar di atas 24 (dua puluh empat butir soal) pada saat UAS.

JAS-PT

ISSN $2580-5339$ eISSN $2620-5718$ Volume 2 Nomor 1 JULI 2018 Hal $39-50$ 
Perlakuan yang sama juga saat dengan pelaksanaan penilaian skor mahasiswa (pebelajar) yang mengikuti tutorial tatapmuka, yaitu misalnya skor/nilai hasil tutorial tatapmuka secara keseluruhan (T-1, T-2, dan T-3) adalah $40 \%$. Maka apabila dijumlah diperoleh nilai akhir mahasiswa (pebelajar) 40\% +40\% $=80 \%$ (memperoleh skor/nilai A). Apabila mahasiswa (pebelajar) hanya dapat menjawab 22 butir (dibawah $\leq 40 \%$ ), maka mahasiswa (pebelajar) sudah dipastikan tidak lulus pada perhitungan nilai akhir pada suatu matakuliah.

\section{Penutup}

Berdasarkan analisis 8 (delapan) komponen penyelenggaraan, analisis sistem penyelenggaraan, analisis manajemen SDM, dan NonSDM dalam penyelenggaraan, analisis pilihan program studi yang akan diselenggarakan dalam PJJ di PTS, dan pilihan analisis modus ganda dalam penyelenggaraan PJJ di PTS, maka penulis menarik simpulan, bahwa kemungkinan besar PJJ dapat diselenggarakan di PTS. Hanya saja diperlukan diskusi-diskusi yang intensif dalam tim, dengan pendampingan para pakar dalam bidang PJJ yang ekspertis berpengalaman dalam praktik menyelenggarakan PJJ (misalnya pakar dari UT).

\section{Daftar Pustaka}

ALA. (1989). Presidential Committee on Information Literacy. Chicago: American Library Association.

Katalog UT, 2017/2018, Sistem Penyelenggaraan FE, FHISIP, FKIP, FMIPA.

Panduan Pelaksanaan Pendidikan Jarak Jauh (PJJ) 2016, Direktorat Jenderal Pembelajaran dan Kemahasiswaan Kementerian Riset, Teknologi, dan Pendidikan Tinggi

Paulina Pannen, 2016, Kebijakan Pendidikan Jarak Jauh dan E-learning di Indonesia, Kemenristek Dikti

S. Udin Winataputra, dkk, 2008, Teori Belajar dan Pembelajaran. Jakata: Universitas Terbuka.

\section{JAS-PT}

IURNAL ANALISS SISTEM PENDIDIKAN TINGG

ISSN $2580-5339$

eISSN $2620-5718$

Volume 2

Nomor 1

JULI 2018

Hal 39- 50 